\title{
Pleomorphic Adenoma of the Cheek. Case Report with Review
}

\author{
Adenoma Pleomórfico de Mejilla. Reporte de Caso con Revisión
}

\author{
Soukayna Bahbah \& Saliha Chbicheb
}

BAHBAH, S. \& CHBICHEB, S. Pleomorphic adenoma of the cheek. Case report with review. Int. J. Odontostomat., 14(4):653$657,2020$.

\begin{abstract}
Pleomorphic adenoma (PA), also called benign mixed tumor, is the most common tumor of the salivary glands. About $70 \%$ of these tumors occur in the parotid gland and an uncommon site are the minor salivary glands. The most common sites of PA of the minor salivary glands are the palate followed by lips and cheek. Other rare reported sites include the fauces, floor of the mouth, tongue, tonsil, pharynx, retromolar area and nasal cavity. Here we report a case of pleomorphic adenoma of minor salivary glands of the cheek in a 22-year-old male. The mass was removed by wide local excision with adequate margins, and the patient was followed for 1-year post operatively with no recurrence.
\end{abstract}

KEY WORDS: pleomorphic adenoma, minor salivary gland, cheek.

\section{INTRODUCTION}

Pleomorphic adenomas are benign salivary gland tumors that represent about $3-10 \%$ of the neoplasm of the head and neck region. They are the most common tumors (50 \%) of the major and minor salivary glands. The palate is considered as the most common intraoral site (42.8-68.8\%), followed by the upper lip (10.1\%) and cheek (5.5\%). Other rare sites include the fauces $(2.5 \%)$, retromolar region $(0.7 \%)$, floor of the mouth and the alveolar mucosa (Aro et al., 2019).

The term Pleomporphic adenoma (PA) was coined by Willis. PA is defined by World Health Organization in 1972 as "a circumscribed tumour characterized by its pleomorphic or mixed appearance clearly recognizable epithelial tissue being intermingled with tissue of mucoid, myxoid or chondroid appearance". The "pleomorphic" nature of the tumor can be explained on the basis of its epithelial and connective tissue elements. The highly variable morphology of this neoplasm is the result of interplay between these elements. There is no difference in behavior of this neoplasm based on proportion of various elements (Chaudhry et al., 1961).
They are more common in adult females from the 3rd to 5th decades (Aro et al.).

PA presents as a mobile slowly growing, painless firm swelling that does not cause ulceration of the overlying mucosa (Garcia Berrocal et al., 2000). Histologically, PA consists of cells with epithelial and mesenchymal differentiation. The treatment of choice is surgical removal with safety margins, to prevent the recurrence. Recurrence has been found for PA, so a periodic follow-up is must, due to the relapse potential and aggressivity of these lesions (Kaneda et al., 1994).

The purpose of this article is to report a rare case of PA of cheek in 22-year-old male patient with characteristic clinical, histological features and treatment.

\section{CASE REPORT}

A 22-year-old male patient reported to our department with the complaint of a slowly growing painless swelling 
in the right cheek region since one year. There was no history of trauma, fevers, disturbance of salivation, sensory changes, or oral surgeries. The past dental and medical history was unremarkable and no other abnormalities were found.

Intraoral examination revealed a firm, globular swelling measuring about $1 \mathrm{~cm} \times 1 \mathrm{~cm}$ in the middle part of the buccal mucosa, sitting close to the parotid gland duct, and opposite the site of right maxillary premolars teeth. The 1 st premolar was in the root state and the 2nd premolar was absent (Fig. 1).

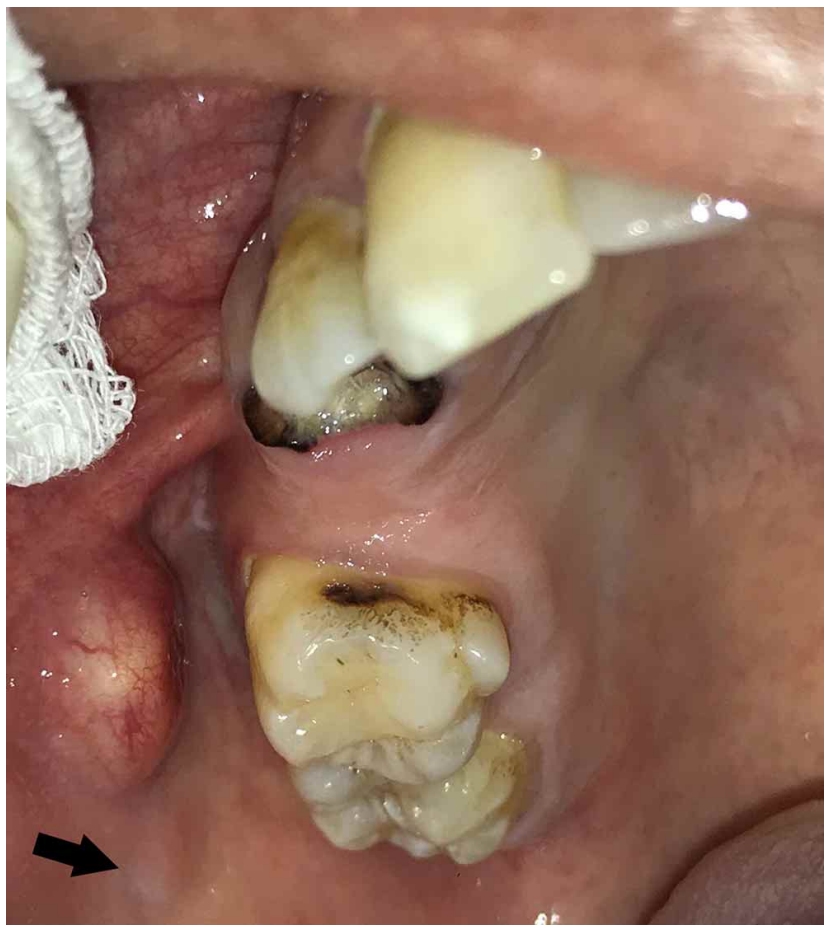

Fig. 1. Preoperative view showing swelling in the right cheek covered by intact mucosa, close to the Stensen's duct.

The swelling was non-tender, non-pulsatile, nonfluctuant, non-reducible and mobile in all planes with well-defined margins. The overlying mucosa was of normal color and texture. On bimanual palpation, the mass could be felt between the cheek mucosa and skin. It was not attached to the surrounding tissue.

Mouth opening was adequate and the cervical lymph nodes were not enlarged. The mass was just underneath the mucosa and away from the parotid gland. The salivary flow was normal with thin and watery consistency.

Radiological examination showed no abnormality in the panoramic radiograph.
Based upon the history and clinical examination, the provisional diagnosis of benign buccal submucosal nodule was made and the differential diagnosis of fibroma, lipoma, neurofibroma, benign minor salivary gland tumor, dermoid cyst, intraoral sebaceous cyst, and hemangioma were considered. But considering the freely movable nature of the mass, the diagnosis of pleomorphic adenoma and lipoma were the most probable. The patient was then advised surgical removal of the mass, with extraction of the 1st premolar right maxillary tooth.

Under local anesthesia, dental extraction of the premolar was performed (Fig. 2). Then, a horizontal incision was made over the "swelling" without injuring the parotid gland duct (Fig. 3). A firm, yellow-white,

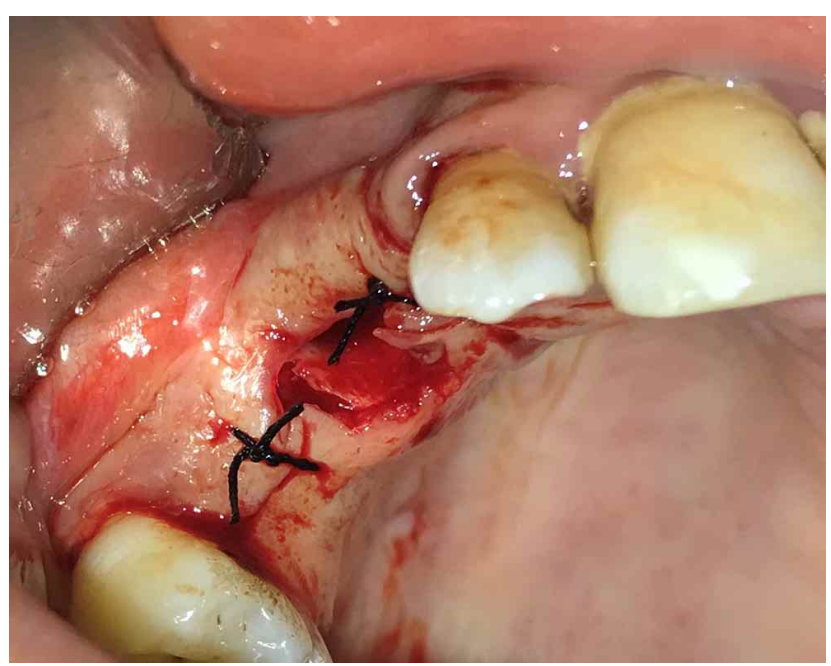

Fig. 2. Extraction of the 1st premolar right maxillary tooth.

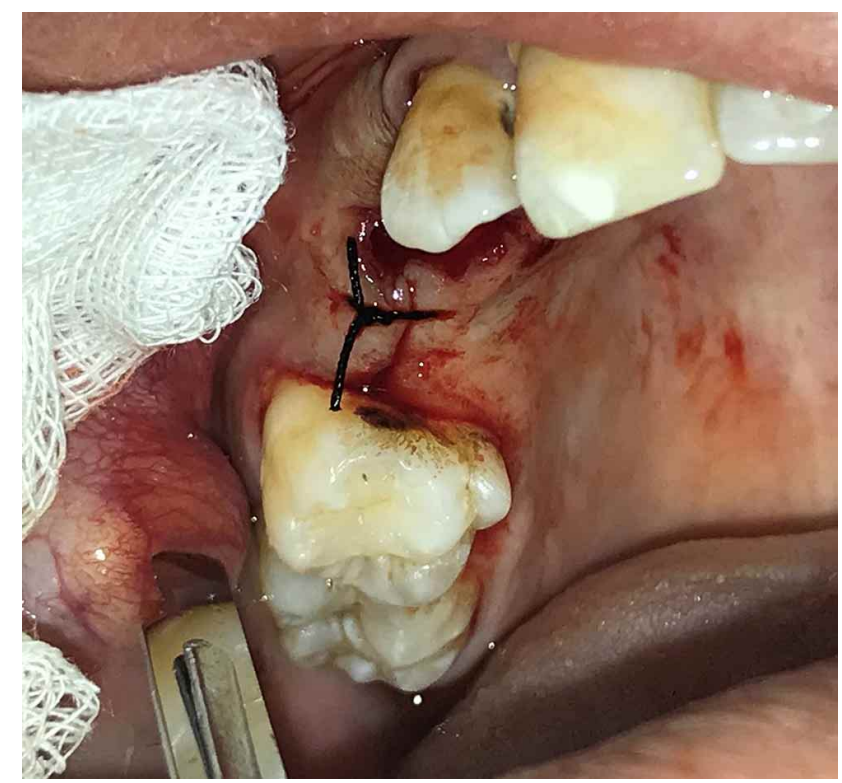

Fig. 3. Horizontal incision performed over the "swelling". 
encapsulated mass was exposed. This was carefully dissected to expose the mass in totality including its capsule, which was present between buccal mucosa and the buccinator muscle (Fig. 4). It was freed from the surrounding tissues and the lesion was excised along with adequate margin of normal tissue (Fig. 5). Hemostasis was achieved and the wound was closed with interrupted sutures. Excised specimen was sent for histopathological examination.

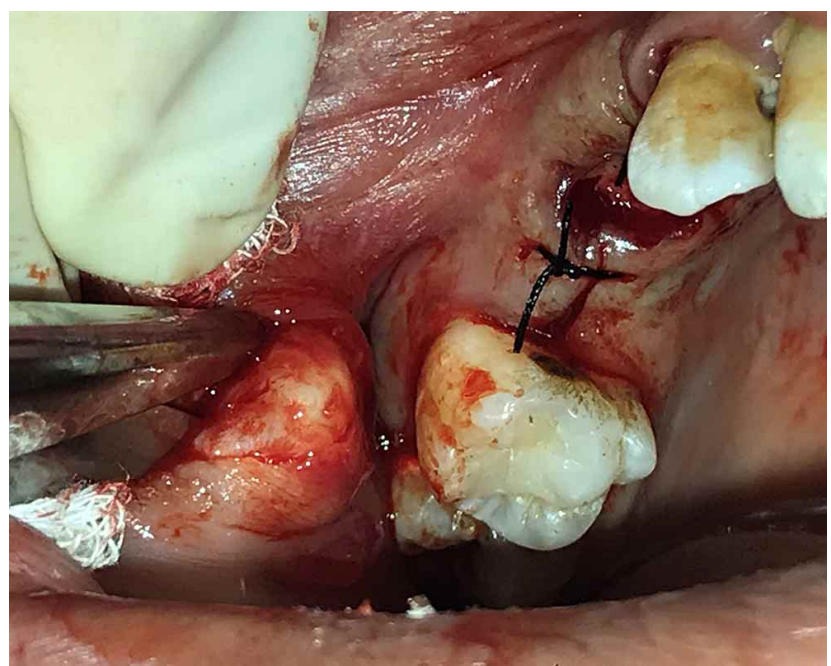

Fig. 4. Exposure of the mass.

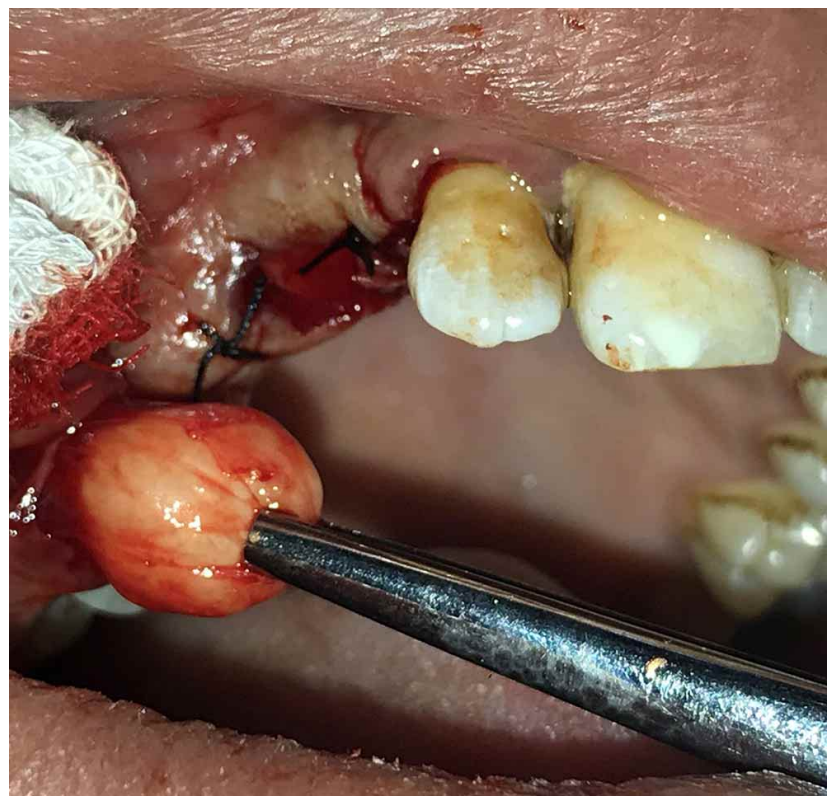

Fig. 5. Lesion freed from the surrounding tissues.

Macroscopically, the lesion was in the form of an ovoid well demarcated, measuring $1.2 ¥ 1 ¥ 0.3 \mathrm{~cm}$ in size, with a whitish, faintly lobulated and focally glistening cut surface (Fig. 6).

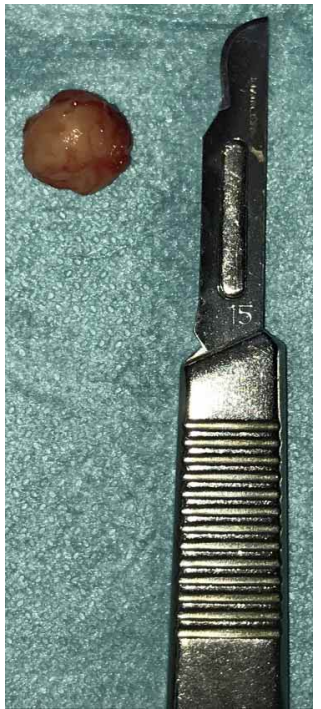

Fig. 6. Excised surgical specimen with a well circumscribed ovoid mass measuring $1.2 \times$ $1 \times 0.3 \mathrm{~cm}$.

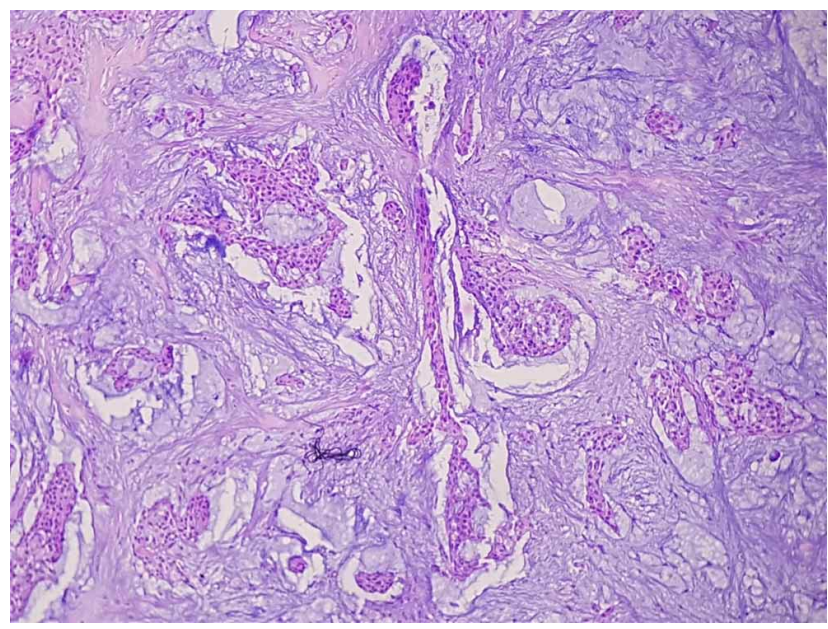

Fig. 7. Photomicrograph of epithelial cells in myxoid connective tissue stroma (hematoxylin-eosin stain, $x$ 100).

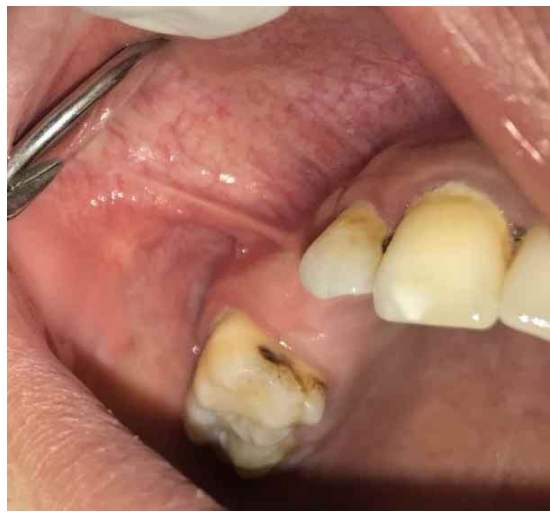

Fig. 8. Postoperative Photograph after 1 year with no evidence of recurrence. 


\section{DISCUSSION}

Pleomorphic adenoma is a benign tumor of the salivary glands. It is the most common tumor of the major and minor salivary glands. Around $70 \%$ of these tumors occur in the parotid gland, $10 \%$ in the submandibular gland and the remainder in the minor salivary glands (Aro et al.).

PA can occur at any age, but are more common in adults than in children, between the ages of 30 and 50 years. Their occurrence is slightly more in women (Chaudhry et al.; Aro et al.).

The site of predilection is the mucosa over the posterior hard palate and anterior soft palate. The cheeks, lips, and gingiva are rare sites of occurrence (Aro et al.).

It presents as a painless, slow growing, firm, mobile mass, irregular in shape, with normal overlying mucosa. These benign neoplasms are usually well circumscribed and round or oval in shape. They vary in consistency from soft and fluctuant to firm and rubbery, depending on the presence of cystic or mucoid degeneration or the formation of chondroid or osteoid tissues (Garcia Berrocal et al.). The size of the tumors range from 1 to $7 \mathrm{~cm}$ in diameter with some PA of cheek may attain larger sizes (Chaudhry et al.). In our case, an ectopic pleomorphic adenoma appeared asymptomatic, mobile, slow growing firm mass. It showed a clinical presentation similar to lipoma.

PA do not invade the underlying structures owing to their benign nature. The malignant transformation rate is about $8.5 \%$. Carcinoma ex pleomorphic adenoma and metastasizing benign mixed tumor are the two variants that undergo malignant transformation (Kaneda et al.). Radiotherapy is not indicated due to the radio resistant behavior of the tumor. Prognosis is excellent (95\%) after complete excision (Garcia Berrocal et al.).

Willis proposed three main hypotheses to explain this kind of heterotopias. These were an abnormal persistence and development of vestigial structures, dislocation of portion of a deficient rudiment during mass movement and development, and abnormal differentiation of the local tissues (heteroplasia). This may happen due to metaplasia, neoplastic degeneration of ectopic salivary gland tissue or due to the implantation after surgical excision of the salivary gland tumor (Kapadia et al., 1997).
Thus ectopic appearance of the pleomorphic adenoma in an unusual location can lead to a diagnostic dilemma to the surgeons and a pathological confirmation is indispensable.

As we know; the buccal space, which constitutes the substance of the cheek, is filled with adipose tissue termed buccal fat pad, parotid duct, minor salivary glands, accessory parotid lobules, the facial and buccal arteries, the facial vein, lymphatic channels, and the branches of the facial and mandibular nerves. The lesions in this space can arise from any of these mentioned structures. So the differential diagnosis of a buccal space lesion includes a tumor originating from glandular, vascular, lymphatic, connective, muscular, ductal, and neural tissues (Pontius \& Myers, 2000).

PA should be differentiated from:

Buccal abscess,

Rhabdomyoma,

Parotid gland cyst and malformation,

Stensen's duct stone, cyst or neoplasm,

Hemangioma, hematoma,

Adnexal tumors (dermoid, lipoma, fibroma, sebaceous cyst),

Benign tumors of accessory parotid tissue,

Neural tumors,

Benign or malignant minor salivary gland tumors,

Benign adenopathy (hyperplasia or adenitis),

Malignant adenopathy (sarcoma, salivary carcinoma, lymphoma),

Malignant primary tumors of accessory parotid tissue, Metastasis.

The diagnostic modalities are imaging which include Ultrasonography, Computed Tomography and Magnetic Resonance Imaging. They are useful in determining the size and extent of lesions and in determining the bone involvement (Spiro, 1986).

Incisional biopsy of PA in situ may predispose to recurrence and is contraindicated (Kaneda et al.).

Fine needle aspiration cytology (FNAC) is controversial. Some authors prefer it and consider that it's a widely accepted preoperative diagnostic tool as the diagnostic accuracy with it is $80-95 \%$ (Sunil \& Gopakumar, 2013). But, others, consider pre-operative needle aspiration biopsy as contraindicated in any benign mixed tumour, as implantation of tumour cells is imminent and dangerous, and might also predispose to recurrence (Pontius \& Myers). 
However, only the pathology exam can confirm the diagnosis. Therefore, in our case, since the lesion was very limited, mobile and covered by thin normal layer of buccal mucosa, not attached to the underlying bony plane, these diagnostic tools were not used. Excisional biopsy was performed and sent for a pathologic confirmation.

Pleomorphic adenoma consists of cells with epithelial (myoepithelial cells) and mesenchymal differentiation (mixed tumor). Histological findings show a mixture of epithelial tissue intermingled with myxoid, mucoid, or chondroid areas (Verma et al., 2014).

The PA has three histological subtypes: myxoid (80 \% stroma), cellular (myoepithelial cells predominating), and mixed (classic). Epithelial cells are arranged in cord-like and duct-like cell patterns, along with areas of epidermoid metaplasia. The intercellular matrix shows fibrous, hyaline, myxoid, cartilaginous, and osseous areas. Myoepithelial cells are responsible for such pleomorphic extracellular matrix production. In the minor glands, lesions are often more solid or cellular than those seen in the major glands, and the myoepithelial cells are often polygonal with a pale eosinophilic cytoplasm giving an epithelioid or plasmacytoid phenotype. Normal salivary architecture in form of acini were observed (Kaneda et al.; Verma et al.).

In our case histopathology report confirmed the diagnosis of PA.

Surgical excision with an adequate margin of normal surrounding tissue is the treatment of choice for PA of the cheek. In our case the lesion was excised intact with its capsule. This is important because incomplete excision, rupture of the capsule, or tumor spillage during excision, might seed tumor cells into the surrounding tissues resulting in recurrence; as these tumors often have microscopic pseudopod-like extensions into the surrounding tissues through the capsule (Willis, 1968). Lower recurrence rates are being reported. Spiro et al., reported a recurrence in $7 \%$ of 1,342 patients with benign parotid neoplasms, and in $6 \%$ of patients with benign minor salivary-gland tumors (Verma et al.). However, recurrences of pleomorphic adenomas after many years have been reported. It was suggested that follow-up examinations be performed for up to 10 years (Verma et al.).

Follow-up of the case after surgery showed smooth healing of the wound with no evidence of recurrence after one year.
BAHBAH, S. \& CHBICHEB, S. Adenoma pleomórfico de mejilla. Reporte de caso con revisión. Int. J.Odontostomat., 14(4):653-657, 2020.

RESUMEN: El adenoma pleomórfico (AP), conocido también como tumor mixto benigno, es el tumor más común de las glándulas salivales. Alrededor del $70 \%$ de estos tumores ocurren en la glándula parótida y con menor frecuencia en las otras glándulas salivales. Los lugares más comunes de AP en las glándulas salivales son el paladar, seguido de labios y mejillas. Otros sitios poco frecuentes reportados, incluyen las fauces, el piso de la boca, la lengua, las tonsilas palatinas, la faringe, el área retromolar y la cavidad nasal. En este estudio se presenta un caso de adenoma pleomórfico de las glándulas salivales menores de la mejilla en un hombre de 22 años. Se extirpó la masa mediante escisión local amplia con márgenes adecuados, con un seguimiento del paciente durante un año después de la operación sin recurrencia.

PALABRAS CLAVE: adenoma pleomórfico, glándula salival menor, mejilla.

\section{REFERENCES}

Aro, K.; Valle, J.; Tarkkanen, J.; Måkitie, A. \& Atula, T. Repeatedly recurring pleomorphic adenoma: a therapeutic challenge. Acta Otorhinolaryngol. Ital., 39(3):156-61, 2019.

Chaudhry, A. P.; Vickers, R. A. \& Gorlin, R. J. Intraoral minor salivary gland tumors. An analysis of 1,414 cases. Oral Surg. Oral Med. Oral Pathol., 14:1194-226, 1961.

Garcia Berrocal, J. R.; Ramirez Camacho, R.; Trinidad, A. \& Salas, C. Mixed tumor (pleomorphic adenoma) of head and neck. Typical and atypical patterns. An. Otorrinolaringol. Ibero Am., 27(4):33340, 2000.

Kaneda, T.; Minami, M.; Ozawa, K.; Akimoto, Y.; Okada, M.; Yamamoto, H.; Suzuki, H. \& Sasaki, Y. Imaging tumors of the minor salivary glands. Oral Surg. Oral Med. Oral Pathol., 78(3):385-90, 1994.

Kapadia, S. B.; Dusenbery, D. \& Dekker, A. Fine needle aspiration of pleomorphic adenoma and adenoid cystic carcinoma of salivary gland origin. Acta Cytol., 41(2):487-92, 1997.

Pontius, A. T. \& Myers, L. L. Pleomorphic adenoma of the buccal space. Otolaryngol. Head Neck Surg., 126(6):695-6, 2000.

Spiro, R. H. Salivary neoplasms: overview of a 35-year experience with 2,807 patients. Head Neck Surg., 8(3):177-84, 1986.

Sunil, S. \& Gopakumar, D. Pleomorphic adenoma: a case report and review of literature. Int. J. Odontostomat., 7(2):171-4, 2013.

Verma, P.; Sachdeva, S. K.; Verma, K. G. \& Sachdeva, K. Pleomorphic adenoma of cheek: a rare case report and review of literature. Indian J. Dent. Res., 25(1):122-4, 2014.

Willis, R. A. Some unusual developmental heterotopias. Br. Med. J., 3(5613):267-72, 1968.

Corresponding author:

Soukayna Bahbah

BP 6212

Madinat Al Irfan

Rabat

MOROCCO

Received: 15-03-2020

Accepted: 08-05-2020

Email: soukayna.bahbah@um5s.net.ma 